\title{
Pathological and parasitological findings in a wild red titi monkey, Callicebus cupreus (Pitheciidae, Platyrrhini)
}

\author{
Britta Müller • Kerstin Mätz-Rensing • \\ Jenni G. Pérez Yamacita • Eckhard W. Heymann
}

Received: 31 August 2009 /Revised: 19 November 2009/Accepted: 4 December 2009/Published online: 5 January 2010

(C) The Author(s) 2009. This article is published with open access at Springerlink.com

\begin{abstract}
An adult female red titi monkey (Callicebus cupreus) was found in a moribund state below a sleeping site at the Estación Biológica Quebrada Blanco in Peruvian Amazonia. Before death, the animal showed frequent convulsions. Post-mortem examination revealed the presence of Prosthenorchis elegans (Acanthocephala) in the small intestine. Major pathological findings concerned the digestive tract and the liver. Adult $P$. elegans provoked multifocal subacute to chronic enteritis with formation of ulcers in the small and large intestine. The liver revealed a severe chronic-active granulomatous hepatitis. While the cause of death could not be unambiguously identified, the
\end{abstract}

Communicated by F.-J. Kaup

B. Müller · J. G. Pérez Yamacita • E. W. Heymann $(\bowtie)$

Abteilung Verhaltensökologie und Soziobiologie,

Deutsches Primatenzentrum,

Kellnerweg 4,

37077 Göttingen, Germany

e-mail: eheyman@gwdg.de

B. Müller $\cdot$ K. Mätz-Rensing

Abteilung Infektionspathologie, Deutsches Primatenzentrum,

Kellnerweg 4,

37077 Göttingen, Germany

J. G. Pérez Yamacita

Facultad de Ciencias Biológicas,

Universidad Nacional de la Amazonía Peruana,

Pevas 5ta. cuadra,

Iquitos, Peru

\section{B. Müller}

Bayerisches Landesamt für Gesundheit und

Lebensmittelsicherheit,

Eggenreuther Weg 43,

91058 Erlangen, Germany infestation with $P$. elegans is likely to have played a key role in the pathogenesis of the chronic ulcerative enteritis and subsequent hepatitis; it possibly had a severe and longterm impact on the host's resource utilisation and defence against intruding pathogens and toxins of the digestive tract. The death of the animal is attributed to the chronic inflammatory processes in the digestive tract.

Keywords Callicebus cupreus · Parasitism . Prosthenorchis elegans $\cdot$ Hepatitis · Enteritis

\section{Introduction}

Disease and parasites are increasingly recognised as major selective forces in primate biology (Chapman et al. 2005; Nunn and Altizer 2006). Infestation with gastro-intestinal parasites can be estimated from analyses of faecal samples (e.g., Gillespie 2006) and molecular techniques allow the detection of viruses and bacteria, even from decaying tissue (e.g., Leendertz et al. 2006). In tropical forests, finding freshly dead or dying individuals is a rare event, unless, epidemics cause mass mortality, like the outbreaks of Ebola in chimpanzees and gorillas (Leendertz et al. 2006; Leroy et al. 2004), or when many researchers working simultaneously at a site increase the probability of finding carcasses, like on Barro Colorado island (Milton 1996). Here, we report pathological and parasitological findings from an adult female red titi monkey (Callicebus cupreus) that was found in a moribund state at the Estacion Biológica Quebrada Blanco (EBQB) during a field study on the comparative parasitology of sympatric small New World primates (Müller 2007). 


\section{Materials and methods}

Study site

The observations reported here were made at Estación Biológica Quebrada Blanco (EBQB), in the Amazon lowlands of northeastern Peru $\left(4^{\circ} 21^{\prime} \mathrm{S} 73^{\circ} 09^{\prime} \mathrm{W}\right)$.

\section{Subject}

The titi monkey group consisted of an adult female, an adult male and a juvenile male and was in the process of being habituated for behavioural observations and noninvasive faecal sample collection since the beginning of September 2002. By the time of the incidence reported here, the degree of habituation was still relatively low, and the group usually moved away when detecting an observer.

Pathological and parasitological methods

After death, a necropsy under field conditions was performed. All organs were extracted, weighed and fixated in $10 \%$ formaldehyde for further laboratory analyses. The organs were transferred to the German Primate Center (Göttingen, Germany) and prepared for histological examinations. Tissue samples of the small and large intestine, stomach, liver, pancreas, kidneys, heart, lungs, and adrenal gland were automatically paraffin-embedded (Hypercenter XP; Thermo Shandon, Pittsburgh, USA), sectioned at $3 \mu \mathrm{m}$ and stained with haematoxylin-eosin. Additionally, sections of the intestines, liver and spleen were stained with Ziehl-Neelsen, Grocott, periodic acid Schiff reaction and Giemsa. Sections of an abdominal cyst were stained with Masson's Trichrome stain. Histological examinations were performed with a Zeiss Axiophot compound light microscope (Carl Zeiss, Oberkochen, Germany). Macroscopic and histological findings were recorded in a standard examination protocol and documented photographically. The morphological features of the adult parasite specimen were examined by dissecting microscope and documented by pictures of scanning electron microscope.

\section{Results}

Field observations

On 29 Sep 2002 at 05.35 h, two observers (JGPY and EWH) arrived at the sleeping site of the Callicebus group and detected the female sitting motionless on the forest floor. At $05.45 \mathrm{~h}$ the female suddenly showed severe convulsions for about $10 \mathrm{~s}$, thereafter, the female remained immobile in a comatose state and did not show any reaction upon touching it. Therefore, the female was transferred to the camp for further examination. There it was placed on a table, where it suddenly showed convulsions again. An external adspection, to which the female did not show any response, revealed no signs of injury.

The female was strongly hypothermic; rectal temperature measured with a mercury thermometer was $35^{\circ} \mathrm{C}$. Eyes were half closed. Neither eye movements nor pupil reflexes could be evoked, nor were pain reactions apparent when the skin of the hand and foot palm was slightly penetrated (ca. $0.5 \mathrm{~mm}$ deep) with a needle. Short bouts of convulsions were observed repeatedly before the female died at $07.50 \mathrm{~h}$. The female weighed $720 \mathrm{~g}$; it was skinny, dehydrated and the pelage was dirty.

\section{Pathology and parasitology}

(a) Macroscopic pathology. The post-mortem necropsy performed immediately after death revealed the following macroscopic findings: The stomach contained remains of fruit and a few young leaves. Although the stomach was full, few digesta were present in the intestines. In the ileum, we found two parasites of 17 and $30 \mathrm{~mm}$ length, respectively, attached to the gut wall which showed an altered mucosa. The parasites' bodies were protruding into the intestinal lumen. In the large intestine, several ulcers were visible, ranging from 1 to $4 \mathrm{~mm}$ in diameter. No parasites were found attached to these lesions.

(b) Histopathology. The two parasites were firmly attached to the intestinal wall of the ileum by embedding their hooked proboscis into the mucosa and submucosa (Fig. 1). The adult parasites were not pseudo-

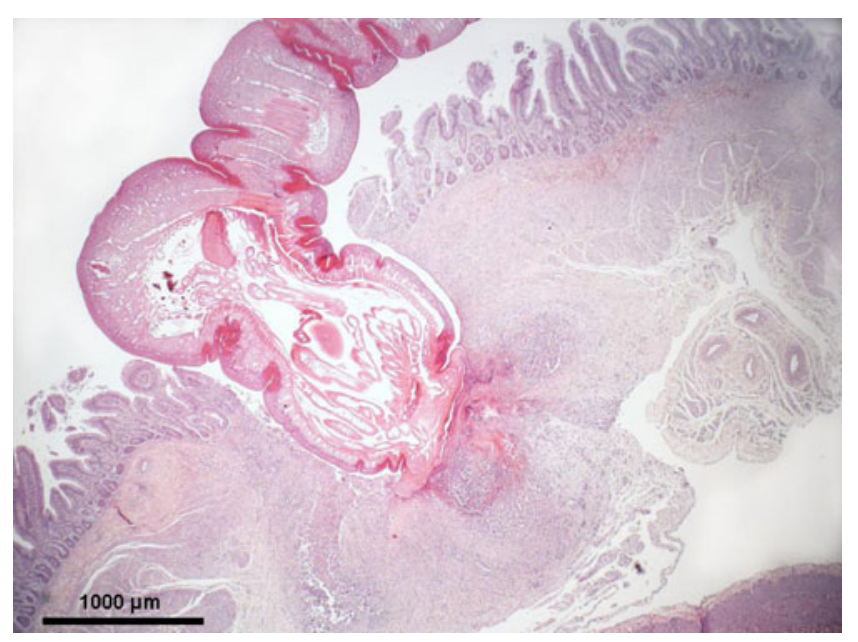

Fig. 1 Light microscopic picture of an adult Prosthenorchis elegans in the ileum of a female Callicebus cupreus. Cross-section of the anterior end and proboscis of P. elegans which intrudes deeply into the intestinal wall, provoking mixed inflammatory cell infiltration, $H \& E$ stain. Scale bar $=1,000 \mu \mathrm{m}$ 
segmented and possessed a spheroid, spinous proboscis with six spiral rows each consisting of five to seven hooks. Below these hook rows was a collar of festoons. These morphological characteristics clearly determined these parasites as $P$. elegans. At the site of attachment of the parasites, sharply delineated mucosal ulcers were present. The ulcers extended into the lamina submucosa and tunica serosa and were surrounded by connective tissue. The infestation with P. elegans was associated with a diffused chronic enteritis. The ulcers were surrounded by necrotic debris, fibroblastic tissue and mixed inflammatory cell infiltration composed by neutrophils, eosinophils, lymphocytes and macrophages (Fig. 2). In only very few sites, scar tissue formation was represented by dense connective tissue extending to the serosal surface. Severe multifocal chronic-active enteritis was evident; several subacute ulcers were demonstrable.

In the liver, disseminated red pin tip-sized lesions were present on the diaphragmatic and visceral surface of the liver. Histology of the liver specimens revealed a severe chronic-active multifocal granulomatous hepatitis, characterised by multiple microgranulomas consisting of necrotic hepatocytes and inflammatory cells, especially lymphocytes, neutrophils and activated Kupffer cells. Multifocal fibrosis with focal calcification was evident in the centrolobular area. Further findings included focal gallstone formation and a mild chronic fibroblastic pericholangitis.

A cyst of approximately $5 \mathrm{~mm}$ in diameter with a white, slender parasite was found retroperitoneally in the paramedian area of the abdominal cavity. Based on morphological features like ventral mouth with four hooks, striated

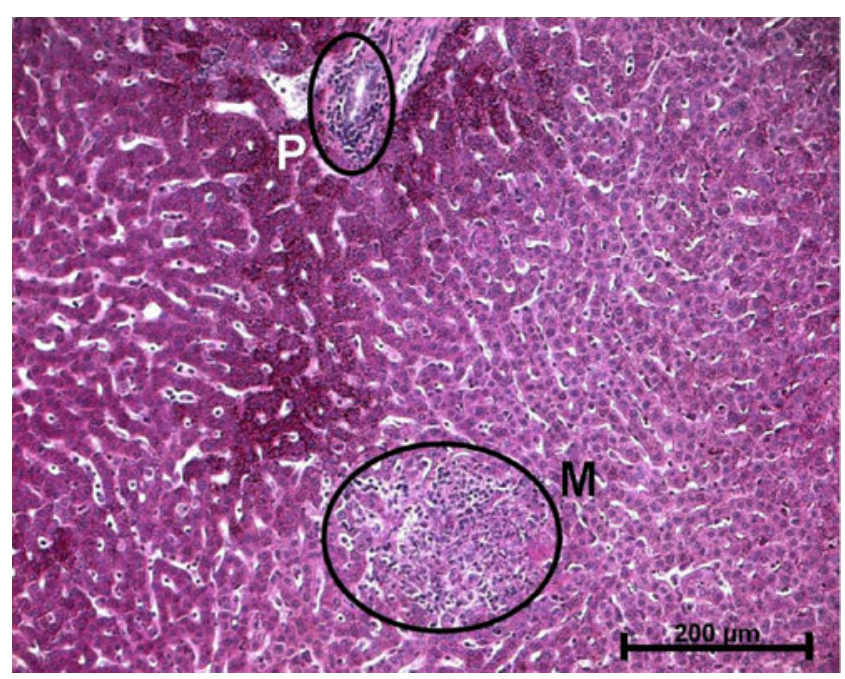

Fig. 2 Section of the liver, showing microgranuloma $(M)$ and pericholangitis $(P)$, PAS stain. Scale bar $=200 \mu \mathrm{m}$ muscles and the structure of the body, the parasite was identified as a pentastomid nymph from the order Porocephalida.

There was severe lymphoid depletion of the spleen with absence of follicular structures. The lung showed mild peripheral alveolar emphysema and mild alveolar histiocytosis. Mild focal lymphocytic infiltration was observed within the adrenal medulla. No bacteria or fungi were observed in specially stained tissue sections.

\section{Discussion}

P. elegans is a common parasite of wild and captive New World primates (Dunn 1963; King 1993; Lehner 1984; Potkay 1992). It can cause severe and fatal pathologies, and infestation with this acanthocephalan parasite has been identified as a major cause of illness or death in captive colonies (e.g., Saguinus oedipus, Callithrix jacchus: Richart and Benirschke 1963; Saimiri sp.: Horna and Tantalean 1990; Saguinus mystax: Gozalo and Montoya 1991). This parasite has not been reported from captive Callicebus cupreus and wild Callicebus brunneus, based on faecal analyses (Michaud et al. 2003; Phillips et al. 2004), but was detected in one of three Callicebus sp. necropsied from Bolivia (Yagi et al. 1988), and C. cupreus (origin not given) is reported as a host of $P$. elegans by Tantaleán and co-workers (2005).

From analyses of multiple faecal samples, there was no evidence for infestation with $P$. elegans in the other $C$. cupreus individuals studied by Müller (2007), but in individuals from the two sympatric tamarin species. Either other $C$. cupreus were not infested or the egg output may have been too low to be detected by conventional parasitological analyses.

The body mass of the titi monkey was below the range of adult body mass (750-1,120 g) reported for this species (Bicca-Marques et al. 2002; Smith and Jungers 1997). The pathological findings coincide with reports from P. elegans infestations in other primates (King 1993; de Melo 2004). Whether the infestation with this parasite was the cause of death cannot be determined. Nevertheless, the chronic enteritis and the presence of ulcers and scars in the intestinal walls due to former infestations with $P$. elegans may have compromised digestive functions and reduced the barrier function of the intestinal walls against the intrusion of pathogens and toxins. Additionally, the severe hepatitis and the lymphoid depletion of the spleen may have impaired metabolic and immune functions. Peritonitis which can result when $P$. elegans penetrate the intestinal wall has been reported as cause of death (Kuntz 1982; Richart and Benirschke 1963; Takos and Thomas 1958) but can be excluded in the present case. 
Since no inflammatory reactions were present, the infestation with a pentastomid is unlikely to have contributed to pathological effects in the female $C$. cupreus. The only other reported case of a pentastomid infestation in Callicebus concerned an individual also infested with $P$. elegans (Yagi et al. 1988).

Acknowledgements All work complied with legal requirements of the countries (Peru, Germany) where the respective parts of the study were conducted and with the institutional ethical guidelines. Field work in Peru and exportation of the material for histopathological examination was carried out under permission from the Instituto Nacional de Recursos Naturales (INRENA) in Lima. We are grateful to N. Shahuano Tello for field assistance, V. Raygada Guerra and C. Lopez Wong for their help with the post-mortem examination at the field camp, H. Zuri, E. Lischka and W. Henkel for technical assistance with histopathology at DPZ and Prof. D.W. Büttner and C. Schmetz from the Bernhard-Nocht-Institute in Hamburg. Finally, we thank two anonymous reviewers for their helpful comments on the manuscript.

Open Access This article is distributed under the terms of the Creative Commons Attribution Noncommercial License which permits any noncommercial use, distribution, and reproduction in any medium, provided the original author(s) and source are credited.

\section{References}

Bicca-Marques JC, Garber PA, Azevedo Lopes MAO (2002) Evidence of three resident adult male group members in a species of monogamous primate, the red titi monkey (Callicebus cupreus). Mammalia 66:138-142

Chapman CA, Gillespie TR, Goldberg TL (2005) Primates and the ecology of their infectious diseases: how will anthropogenic change affect host-parasite interactions? Evol Anthropol 14:134-144

de Melo AL (2004) Helminth parasites of Callithrix geoffroyi. Lab Primate Newsl 43(2):7-9

Dunn FL (1963) Acanthocephalans and cestodes of South American monkeys and marmosets. J Parasitol 49:717-722

Gillespie TR (2006) Noninvasive assessment of gastrointestinal parasite infections in free-ranging primates. Int $\mathrm{J}$ Primatol 27:1129-1143

Gozalo A, Montoya E (1991) Mortality causes of the moustached tamarin (Saguinus mystax) in captivity. J Med Primatol 21:35-38

Horna M, Tantaleán M (1990) Parásitos del primates peruanos: helmintos del "mono fraile" y del "pichico barba blanca". In: Proyecto Peruano de Primatología (ed) La Primatología en el
Perú. Investigaciones Primatológicas (1973-1985). Imprenta Propaceb, Lima, pp 555-564

King NW Jr (1993) Prosthenorchiasis. In: Jones TC, Mohr U, Hunt RD (eds) Nonhuman primates vol. 2. Springer, Berlin, pp 65-68

Kuntz RE (1982) Significant infections in primate parasitology. J Hum Evol 11:185-194

Leendertz FH, Pauli G, Maetz-Rensing K, Boardman W, Nunn C, Ellerbrok H, Jensen SA, Junglen S, Boesch C (2006) Pathogens as drivers of population declines: the importance of systematic monitoring in great apes and other threatened mammals. Biol Conserv 131:325-337

Lehner NDB (1984) Biology and diseases of Cebidae. In: Fox JF, Cohen BJ, Loew FM (eds) Laboratory animal medicine. Academic, Orlando, pp 321-353

Leroy EM, Rouquet P, Formenty P, Souquiere S, Kilbourne A, Froment JM, Bermejo M, Smit S, Karesh W, Swanepoel R, Zaki SR, Rollin PE (2004) Multiple Ebola virus transmission events and rapid decline of Central African wildlife. Science 303:387390

Michaud C, Tantalean M, Ique C, Montoya E, Gozalo A (2003) A survey for helminth parasites in feral New World non-human primate populations and its comparison with parasitological data from man in the region. J Med Primatol 32:341-345

Milton K (1996) Effects of bot fly (Alouattamyia baeri) parasitism on a free-ranging howler monkey (Alouatta palliata) population in Panama. J Zool, Lond 239:39-63

Müller B (2007) Determinants of the diversity of intestinal parasite communities in sympatric New World primates (Saguinus mystax, Saguinus fuscicollis, Callicebus cupreus). Doctoral thesis, Tierärztliche Hochschule Hannover

Nunn CL, Altizer S (2006) Infectious diseases in primates. Oxford University Press, Oxford

Phillips KA, Haas ME, Grafton BW, Yrivarren M (2004) Survey of the gastrointestinal parasites of the primate community at Tambopata National Reserve, Peru. J Zool, Lond 264:149-151

Potkay S (1992) Diseases of the Callitrichidae: a review. J Med Primatol 21:189-236

Richart R, Benirschke K (1963) Causes of death in a colony of marmoset monkeys. J Pathol Bacteriol 86:221-223

Smith RJ, Jungers WL (1997) Body mass in comparative primatology. J Hum Evol 32:523-559

Takos MJ, Thomas LJ (1958) The pathology and pathogenesis of fatal infections due to an acanthocephalid parasite of marmoset monkeys. Am J Trop Med Hyg 7:90-94

Tantaleán M, Sánchez L, Gómez L, Huiza A (2005) Acantocéfalos del Perú. Rev Peru Biol 12:83-92

Yagi K, Minezawa M, Grock TR (1988) Helminth parasites of Bolivian cebid monkeys. Kyoto Univ Overs Res Rep New World Monkeys 6:51-55 